\title{
Have Debit Cards Changed Thai Consumer Shopping Behavior?
}

\author{
Chetsada Noknoi \\ Economics and Business Administration Faculty, Thaksin University \\ 140 Moo 4, Kanajanavanit Rd., Muang, \\ Songkhla 90000, Thailand \\ Tel: 66-8-9777-8219Ｅ-mail: cnoknoi@hotmail.com \\ Sutee Ngowsiri \\ Economics and Business Administration Faculty, Thaksin University \\ 140 Moo 4, Kanajanavanit Rd., Muang, \\ Songkhla 90000, Thailand \\ Tel: 66-8-1738-0957Ｅ-mail: sutee@tsu.ac.th \\ Wannaporn Boripunt \\ Economics and Business Administration Faculty, Thaksin University \\ 140 Moo 4, Kanajanavanit Rd., Muang, \\ Songkhla 90000, Thailand \\ Tel: 66-8-9655-2996 E-mail: ca_ca500@hotmail.com
}

The earlier draft of this paper was presented at the 8th International Conference on Knowledge, Culture and Change in Organisations, August, 5-8, 2008, Cambridge University, United Kingdom. It based on the study of "Behavior and Quality Perceiving on Using Debit Card of the Consumers in Songkhla Province" that was financial supported by Research and Development Institute Thaksin University, Thailand.

\begin{abstract}
This research aims to study the behavior of using debit cards and the quality perceiving on using debit cards of the consumers in Songkhla Province, Thailand. Questionnaires were used for data collection by purposive sampling and equally distributed to 303 consumers who held at least 1 debit card and used it 3 months before the study. The collected data was analyzed using the descriptive statistics; frequency and percentage, and the inferential statistics; Pearson chi-square at the .05 level of statistics significance.

This research found that the demographic characters of the consumers were female, between 21-30 years old, and held bachelor degree. Two-thirds of consumers were students, government and company officers. More than half of them earned 5,001 - 15,000 baht per month. The research also found that the consumers had only 1 debit card and most of them were Visa type. Most of their debit cards were issued by Bangkok Bank. They owned debit card for 1-2 years. Ratio of withdraw to payment is 40:60. They used debit card for withdrawing 2-3 times a month and 1,001-3,000 baht each time. They used debit card for expense 2-3 times a month and $500-1,000$ baht each time. They frequently used their debit card at department store and paid for their infrastructures. Debit card made a little change on their expense behavior especially in food and drink consumption. This research also found that most of consumers well perceived on the service quality in all dimension of tangible, reliability, responsiveness, assurance, and empathy. This research found that service marketing mixes influenced on using debit card behavior are debit card, promotion, process, physical evidences, and productivity and quality control. The research also found that all service marketing mix influenced on quality perceiving on using debit card. The information from this research is beneficial to set debit card marketing mix strategy policy to stimulate consumer behavior on using debit card.
\end{abstract}

Keywords: Debit card, Shopping, Consumer behavior, Quality perception 


\section{Introduction}

The progress of information technology, communication, and the Internet system has forced the financial and banking system to be globalized. It is not convenient any more to bring much money for buying products and services. Banks play an important role in managing money transaction. They have created many new financial tools, such as ATM cards and credit cards to increase the convenience and ease of the economic system. These financial innovations support transactions and stimulate consumption. At the same time, card issuers make income from the fees (Manager, 2005). Besides providing more convenience and safety than cash, consumers can use their debit cards to withdraw cash at the ATM. Increasing debit card use reduces the Thai government's expenses for producing banknotes. Even though debit cards look like credit cards or ATM cards, there are differences in their function. Credit cards mean "buy first-pay later" while debit cards mean "buy now-pay now. When using debit card, it will directly connect to your account and will credit the amount from your account to the vendor once you buy a product or service (Foundation for Consumers, 2007).

A market survey of debit card using in Thailand found that debit card holders increased 27 percent to 12 million cards at the end of March, 1996. However only 4.5 billion baht was spent using debit cards, 20 percent increase (Weekly Manager, 1996). While 95 percent of Thai people used debit card for withdrawing the money via ATM, only 5 percent used debit card for purchasing. The main reasons are the inadequate advantage consumers perceive for using their debit cards and distrust in online payment system. To change consumer behavior, banks must actively market the advantages of debit card use (BrandAge, 1995). With the increasing of the number of debit card holders but only small proportion using the card for purchasing including new ways in payment such as mobile payment, commercial bank must be focus on making consumers understand how to use debit card.

The objective of this research is to study the consumer's using debit card behavior, the consumer's service quality perception, and the service marketing mix that relate to behavior and perception of the consumer. The research will concentrate on the consumer in Songkhla Province, Thailand, who held at least one debit card and used it three months before the study.

\section{Literature Review}

\subsection{Consumer Behavior}

Today's world understanding consumer behavior and knowing customers are never simple because customers may say one thing but do another. The study of consumer behavior enables marketers to understand and predict consumer behavior in the marketplace. It focuses on how individuals make decisions to spend their available resources (time, money, effort) on consumption-related items that includes what they buy, why they buy it, when they buy it, where they buy it, how often they buy it, and how often they use it (Schiffman \& Kanuk, 2000).

Kotler (2000) stated that consumer behavior studies how individuals, groups, and organizations select, buy, use, and dispose of goods, services, ideas, or experiences to satisfy their needs and desires. While, Engel, Blackwell \& Miniard (1995) defined consumer behavior as those activities directly involved in obtaining, consuming, and disposing of products and services, including the decision processes the precede and follow these actions.

Consumer behavior is influenced by four factors: cultural (culture, subculture, and social class); social (reference groups, family, and social roles and statuses); personal (age, stage in the life cycle, occupation, economic circumstances, lifestyle, personality, and self-concept); and psychological (motivation, perception, learning, beliefs, and attitudes) (Zeithaml, 1988). Research into all these factors can provide clues as to how to reach and serve consumers more effectively.

To understand how consumers actually make their buying decisions, marketers must identify who makes and has input into the buying decision; people can be initiators, influencers, deciders, buyers, or users and different marketing campaigns might be targeted to each type of person.

\subsection{Service}

A service is any act or performance that one party can offer to another that is essentially intangible and does not result in the ownership of anything (Kotler, 2000). Its production may or may not be tied to a physical product.

Services have four major characteristics that greatly affect the design of marketing program: intangible, inseparable, variable, and perishable (Kotler, 2000). Each characteristic poses challenges and requires certain strategies. Marketers must find ways to give tangibility to intangibles; to increase the productivity of service providers; to increase and standardize the quality of the service provided; and to match the supply of services during peak and nonpeak periods with market demand (Parasuraman, 2000). 


\subsection{Service Quality}

Service marketers frequently complain about the difficulty of differentiating their services (Kotler, 2000). Consumers often judge the quality of service on the basis of a variety of informational cues that they associate with the service (Zeithaml, Berry \& Parasuraman, 1996). It is more difficult for consumers to evaluate the quality of services than the quality of products (Woodside \& Taylor, 1978). This is true because of certain distinctive characteristics of services: They are intangible, they are variable, they are perishable, and they are simultaneously produced and consumed. To overcome the fact that consumers are unable to compare services side-by-side as they do with competing products, consumers rely on surrogate cues (i.e., extrinsic cues) to evaluate service quality (Schiffman \& Kanuk, 2000).

Parasuraman, Zeithaml \& Berry (1985) formulated a service-quality model that highlights the main requirements for delivering high service quality. The model identifies five gaps that cause unsuccessful delivery:

1) Gap between consumer expectation and management perception: Management does not always perceive correctly what customer want.

2) Gap between management perception and service-quality specification: Management might correctly perceive the customers' wants but not set a specified performance standard.

3) Gap between service-quality specifications and service delivery: The personnel might be poorly trained, or incapable or unwilling to meet the standard. Or they may be held to conflicting standards, such as taking time to listen to customers and serving them fast.

4) Gap between service delivery and external communications: Consumer expectations are affected by statements made by company representatives and ads.

5) Gap between perceived service and expected service: This gap occurs when the consumer misperceives the service quality.

Berry \& Parasuraman (1991) found five determinants of service quality. These are presented in order of importance.

1) Reliability: The ability to perform the promised service dependably and accurately.

2) Responsiveness: The willingness to help customers and to provide prompt service.

3) Assurance: The knowledge and courtesy of employees and their ability to convey trust and confidence

4) Empathy: The provision of caring, individualized attention to customers

5) Tangibles: The appearance of physical facilities, equipments, personnel, and communication materials.

In accordance with the literature, the developed conceptual framework is shown in Figure 1.

\section{Insert Figure 1 here}

In order to test the influent factors, demographic characteristic and service marketing mix, that effect to the consumer behavior and the service quality perception, four hypotheses were tested in this study. There were:

Hypothesis 1: The relationship between the demographic characteristics and the debit card using behavior.

Hypothesis 2: The relationship between the demographic characteristics and the service quality perception.

Hypothesis 3: The relationship between the service marketing mixes and the debit card using behavior.

Hypothesis 4: The relationship between the service marketing mixes and the service quality perception.

\section{Research Methodology}

The population of this research will concentrate on the consumer in Songkhla Province, Thailand, who held at least one debit card and used it three months before the study. Questionnaires were used for data collection by purposive sampling and equally distributed to 303 consumers who held at least 1 debit card and used it 3 months before the study. The questionnaire for this research was comprised of three sections. Section one contained items on demographics details of the respondent. Section two contained the questions related to the consumer behaviors. Section three contained the modified SERVQUAL items to measure consumer service perceptions. The collected data was analyzed using the descriptive statistics; frequency and percentage, and the inferential statistics; Pearson chi-square at the 0.05 level of statistics significance.

In order to test the reliability of the marketing mixes and the SERVQUAL five dimensions, Cronbach's alpha coefficient were computed. The result from testing show that the Cronbach's alpha coefficient of both service marketing mixes and service quality perception were high level which are $0.8310-0.8853$ and $0.8340-0.8838$ respectively.

\section{Results}

This research found that the demographic characters of the consumers were female $(62.0 \%)$, between 21-30 years old $(38.6 \%)$, and held bachelor degree (65.4\%). Two-third of consumers was students, government and company officers. 
More than half of them earned 5,001 - 15,000 baht per month (52.8\%). The majority of consumers had only 1 debit card (71.9\%) advised by bank officer. Most of the card were Visa type (81.1\%) and issued by Bangkok Bank (35.6\%). They owned debit card for 1-2 years (40.3\%) and had the ratio of withdraw to payment for 40:60. They used debit card for withdrawing 2-3 times a month $(40.3 \%)$ and 1,001 - 3,000 baht each time (37.0\%) and spending 2-3 times a month (39.2\%) with $500-1,000$ baht each time (34.0\%). They frequently used their debit card at department store (64.4\%) and paid for their infrastructures $(22.9 \%)$. Debit card made a little change by increasing their expense behavior especially in food and drink consumption (28.4\%). Moreover, salesperson is the most influence person to the consumer for using the debit card instead of cash in payment.

For the first hypothesis test result, focused on the relationship between the demographic characteristics and the using debit card behaviors of the consumers, the research found that the consumer behavior is dependent on demographic characteristic especially on occupation, income, and marital status as shown in Table 1.

\section{Insert Table 1 here}

The second hypothesis test result, focused on the relationship between the demographic characteristics and service quality perception of the consumers, the research found that service quality perception of the consumers is dependent on demographic characteristic especially on gender, age, education, occupation, and income. However consumer perceived service quality appear to be independent on marital status as shown in Table 2.

\section{Insert Table 2 here}

The third hypothesis test result, focused on the relationship between the service marketing mixes and the using debit card behavior of the consumers, the research found that the consumer behavior is dependent on product, place, promotion, people, process, physical evidence, and productivity and service quality. However the behavior is independent on price which is the annual fee as shown in Table 3.

\section{Insert Table 3 here}

The last hypothesis test result, focused on the relationship between the service marketing mixes and service quality perception of the consumers, the research found that service quality perception of the consumer is dependent on the service marketing mixes as shown in Table 4.

\section{Insert Table 4 here}

\section{Discussion and Conclusion}

The aim of this research is to study the behavior of using debit card and the quality perceiving on using debit card of the consumer in Songkhla Province, Thailand. The research found that the demographic characters of the consumers were female, between 21-30 years old, and held bachelor degree. Two-third of consumers was students, government and company officers. By studying their demographic, this result can lead the issuing bank to pay the attention or define strategy to the right target group and expand the market to the new target group such as male. The research also found that more than half of the respondent earned 5,001 - 15,000 baht per month. This will cause from the minimum income for applying the credit card is 15,000 baht. Therefore, the consumer who has the income more than 15,000 baht will prefer to have the credit card than debit card.

For consumer behavior, the research found that most of the consumer had only one debit card and used it for spending more than withdrawing. This is the good signal as in the past the consumer used the debit card as ATM. Even if they used debit card for spending in the same frequency as withdrawing but the amount is only $500-1,000$ baht each time. They frequently used their debit card at department store and paid for their infrastructure more than spending on product and service. Moreover, the debit card made a little change on their expense behavior especially on food and drink consumption. The issuing back should be coordinate with merchants to motivate the consumer to use debit card more on spending. Moreover, the research result shown that all aspects of service marketing mixes is effect to their perception, the issuing bank should be increase the consumer quality perception by using the appropriate service marketing mixes.

\section{References}

Berry, L. \& Parasuraman, A. (1991). Marketing Services: Competing Through Quality. New York: The Free Press. BrandAge. (1995). Plastic Card: The Progress of Money, October, 43-55.

Engel, J. F., Blackwell, R.D., \& Miniard, P.W. (1995). Consumer behavior. $\left(8^{\text {th }}\right.$ ed.). Chicago: the Dryden Press.

Foundation for Consumers. (2007). Forcing by Bank to Have Debit Card. [Online] Available: $\mathrm{http}: / /$ www.consumerthai.org/cms/index.php?option=com_content\&task=view \&id=605\&Itemid=38 (Retrieved from February 25, 2008).

Kotler, P. (2000). Marketing management. (10 ${ }^{\text {th }}$ ed.). Upper Saddle River, NJ: Prentice-Hall. 
Manager. (2005). Warning! Debit Owner Beware of Losing, October, 12.

Parasuraman, A. (2000). Superior Service and Marketing Excellence: Two Sides of the Same Success Coin. Vikalpa: The Journal for Decision Makers, 25(3), 3-13.

Parasuraman, A., Zeithaml, V. \& Berry, L. (1985). A Conceptual Model of Service Quality and Its Implications for Future Research. Journal of Marketing, Fall, 41-50.

Schiffman, L. G., \& Kanuk, L. L. (2000). Consumer behavior. (7 ${ }^{\text {th }}$ ed.). Upper Saddle River, NJ: Prentice-Hall.

Weekly Manager. (1996). 7 Years in Failure of Debit Card, Banks Forgot to Promote-Consumers Didn't Familiar, July, 24.

Woodside, A. G., \& Taylor, J. L. (1978). Consumer purchase intentions and perceptions of product quality and national advertising. Journal of Advertising, 7(1), 48-51.

Zeithaml, V. A. (1988). Consumer perceptions of price, quality, and value: a means-end model and synthesis of evidence. Journal of Marketing, July, 2-22.

Zeithaml, V., Berry, L. \& Parasuraman, A. (1996). The Behavioral Consequences of Service Quality. Journal of Marketing, April, 31-46.

Table 1. The relationship between the demographic characteristics and the debit card using behavior of the consumers

*Significant at $95 \%$ level of confidence

\begin{tabular}{|c|c|c|c|c|c|c|c|c|}
\hline \multirow{2}{*}{\multicolumn{2}{|c|}{$\begin{array}{l}\text { Demographic } \\
\text { characteristics }\end{array}$}} & \multicolumn{7}{|c|}{ Debit card using behavior } \\
\hline & & $\begin{array}{l}\text { Period } \\
\text { of time } \\
\text { holding } \\
\text { debit } \\
\text { card }\end{array}$ & $\begin{array}{l}\text { Reason } \\
\text { for } \\
\text { holding }\end{array}$ & $\begin{array}{l}\text { Average } \\
\text { times per } \\
\text { month for } \\
\text { using }\end{array}$ & $\begin{array}{l}\text { Period of } \\
\text { month for } \\
\text { the most } \\
\text { using }\end{array}$ & $\begin{array}{l}\text { Festival } \\
\text { that using } \\
\text { the debit } \\
\text { card }\end{array}$ & $\begin{array}{c}\text { Product/ } \\
\text { service } \\
\text { categories } \\
\text { to buy via } \\
\text { debit card }\end{array}$ & $\begin{array}{l}\text { Influence } \\
\text { for using }\end{array}$ \\
\hline \multirow[t]{2}{*}{ Gender } & $\begin{array}{c}\text { Chi-squar } \\
\text { e }\end{array}$ & 9.997* & 10.141 & 3.548 & 8.593 & $17.133^{*}$ & 23.131 & 14.669 \\
\hline & Sig. & .019 & .255 & .738 & .283 & .029 & .081 & .066 \\
\hline \multirow[t]{2}{*}{ Age } & $\begin{array}{c}\text { Chi-squar } \\
\mathrm{e}\end{array}$ & $53.966^{*}$ & $133.937^{*}$ & $363.451^{*}$ & 78.727 & 93.163 & $401.732 *$ & $875.177^{*}$ \\
\hline & Sig. & .012 & .006 & .000 & .642 & .563 & .008 & .000 \\
\hline \multirow[t]{2}{*}{$\begin{array}{l}\text { Marital } \\
\text { status }\end{array}$} & $\begin{array}{c}\text { Chi-squar } \\
\mathrm{e}\end{array}$ & $36.748^{*}$ & $66.314 *$ & $95.921 *$ & 26.707 & $55.250^{*}$ & $159.656^{*}$ & $332.738^{*}$ \\
\hline & Sig. & .000 & .000 & .000 & .534 & .007 & .002 & .000 \\
\hline \multirow[t]{2}{*}{ Education } & $\begin{array}{c}\text { Chi-squar } \\
\mathrm{e}\end{array}$ & 22.922 & 52.033 & $69.458^{*}$ & 41.096 & 36.241 & $224.228 *$ & $349.362 *$ \\
\hline & Sig. & .194 & .320 & .001 & .511 & .894 & .002 & .000 \\
\hline \multirow[t]{2}{*}{ Occupation } & $\begin{array}{c}\text { Chi-squar } \\
\mathrm{e}\end{array}$ & $80.896^{*}$ & $210.130^{*}$ & $404.774 *$ & $309.210^{*}$ & 206.338 & $1133.860^{*}$ & $2470.170 *$ \\
\hline & Sig. & .010 & .040 & .000 & .000 & .058 & .000 & .000 \\
\hline \multirow[t]{2}{*}{ Income } & $\begin{array}{c}\text { Chi-squar } \\
\text { e }\end{array}$ & $32.225^{*}$ & $104.107^{*}$ & 53.720 & $135.652 *$ & $94.520^{*}$ & $259.278^{*}$ & $476.120^{*}$ \\
\hline & Sig. & .021 & .000 & .106 & .000 & .001 & .001 & .000 \\
\hline
\end{tabular}


Table 2. The relationship between the demographic characteristics and service quality perception of the consumers

*Significant at $95 \%$ level of confidence

\begin{tabular}{|c|c|c|c|c|c|c|}
\hline \multicolumn{2}{|c|}{ Demographic characteristics } & \multicolumn{5}{|c|}{ Service quality perception } \\
\hline & & Tangible & Reliability & Responsive & Assurance & Empathy \\
\hline \multirow[t]{2}{*}{ Gender } & Chi-Square & $8.727 *$ & 5.128 & 5.440 & $7.924 *$ & $13.526^{*}$ \\
\hline & Sig. & .033 & .163 & .142 & .048 & .004 \\
\hline \multirow[t]{2}{*}{ Age } & Chi-Square & $73.297 *$ & $63.412 *$ & $67.349 *$ & $73.743^{*}$ & $75.917^{*}$ \\
\hline & Sig. & .000 & .003 & .034 & .000 & .000 \\
\hline \multirow[t]{2}{*}{ Marital status } & Chi-Square & 16.914 & 14.565 & 17.970 & 14.064 & 17.328 \\
\hline & Sig. & .153 & .266 & .117 & .297 & .138 \\
\hline \multirow[t]{2}{*}{ Education } & Chi-Square & $33.161 *$ & 28.009 & $33.752 *$ & $40.570^{*}$ & 27.864 \\
\hline & Sig. & .016 & .062 & .014 & .002 & .064 \\
\hline \multirow[t]{2}{*}{ Occupation } & Chi-Square & 71.326 & 67.277 & $127.940 *$ & 75.560 & 73.438 \\
\hline & Sig. & .305 & .433 & .004 & .197 & .248 \\
\hline \multirow[t]{2}{*}{ Income } & Chi-Square & $41.904 *$ & $35.509 *$ & $44.484^{*}$ & $33.088 *$ & 33.493 \\
\hline & Sig. & .004 & .025 & .025 & .045 & .218 \\
\hline
\end{tabular}

Table 3. The relationship between the service marketing mixes and the debit card using behavior of the consumers

*Significant at 95\% level of confidence

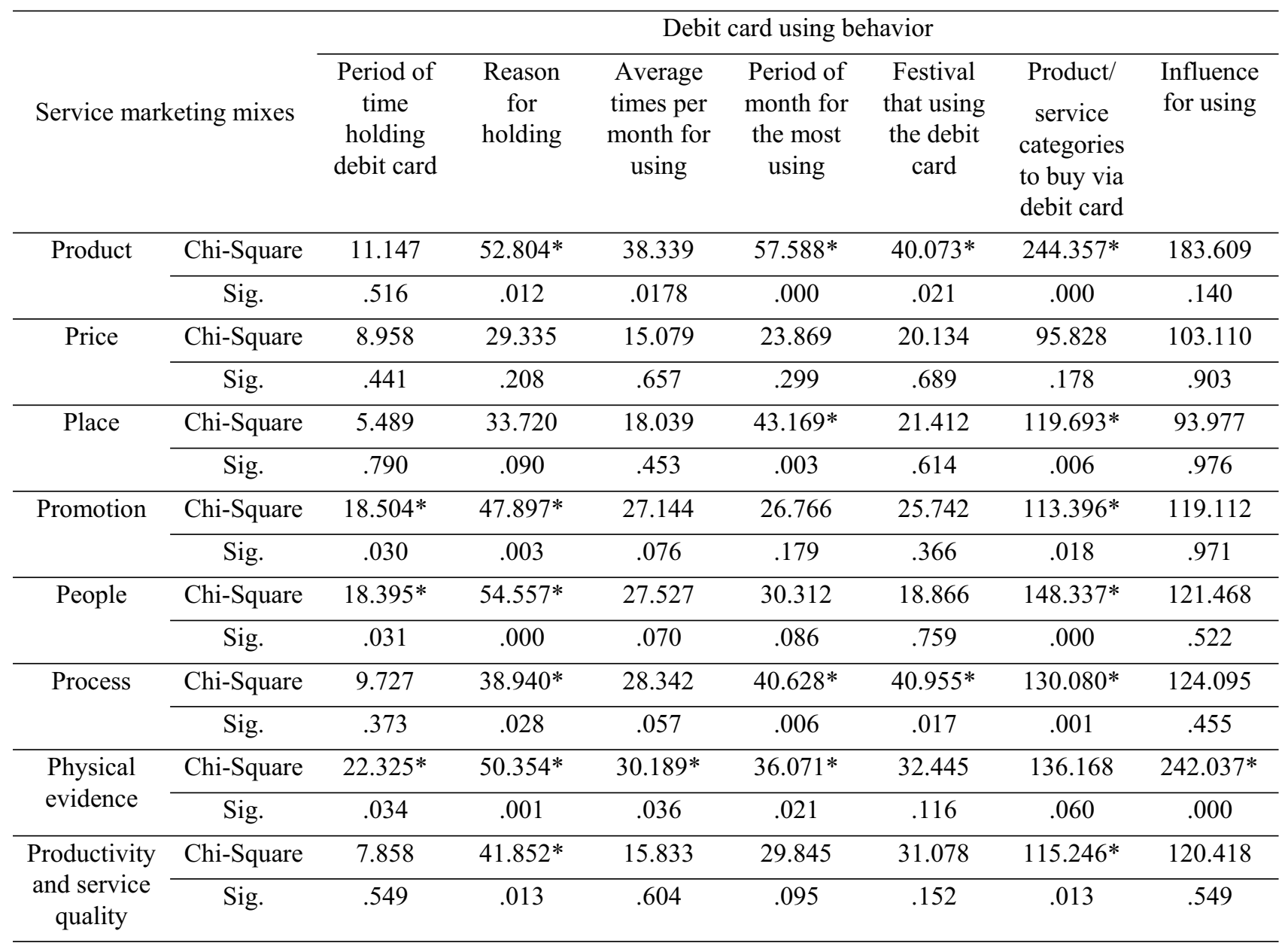


Table 4. The relationship between the service marketing mixes and service quality perception of the consumers

*Significant at $95 \%$ level of confidence

\begin{tabular}{|c|c|c|c|c|c|c|}
\hline \multicolumn{2}{|c|}{ Service marketing mixes } & \multicolumn{5}{|c|}{ Service quality perception } \\
\hline & & Tangible & Reliability & Responsive & Assurance & Empathy \\
\hline \multirow[t]{2}{*}{ Product } & Chi-Square & $51.298 *$ & $28.693 *$ & $57.121 *$ & $39.462 *$ & $58.978 *$ \\
\hline & Sig. & .000 & .001 & .000 & .000 & .000 \\
\hline \multirow[t]{2}{*}{ Price } & Chi-Square & $34.442 *$ & $48.613^{*}$ & $39.094 *$ & $59.261^{*}$ & $43.997^{*}$ \\
\hline & Sig. & .000 & .000 & .000 & .000 & .000 \\
\hline \multirow[t]{2}{*}{ Place } & Chi-Square & $30.040 *$ & $26.791 *$ & $29.457 *$ & $47.412 *$ & $39.202 *$ \\
\hline & Sig. & .000 & .002 & .003 & .000 & .000 \\
\hline \multirow[t]{2}{*}{ Promotion } & Chi-Square & $33.535^{*}$ & $35.296^{*}$ & $34.849 *$ & $36.056^{*}$ & $33.960 *$ \\
\hline & Sig. & .000 & .000 & .000 & .000 & .000 \\
\hline \multirow[t]{2}{*}{ People } & Chi-Square & $46.442 *$ & $40.445^{*}$ & $29.763^{*}$ & $42.472^{*}$ & $39.048^{*}$ \\
\hline & Sig. & .000 & .000 & .000 & .000 & .000 \\
\hline \multirow[t]{2}{*}{ Process } & Chi-Square & $58.419 *$ & $27.145^{*}$ & $48.699 *$ & $45.575^{*}$ & $42.734^{*}$ \\
\hline & Sig. & .000 & .001 & .000 & .000 & .000 \\
\hline \multirow{2}{*}{$\begin{array}{l}\text { Physical } \\
\text { evidence }\end{array}$} & Chi-Square & $34.126^{*}$ & $37.316^{*}$ & $33.843^{*}$ & $32.440^{*}$ & $23.568 *$ \\
\hline & Sig. & .001 & .000 & .000 & .001 & .005 \\
\hline \multirow{2}{*}{$\begin{array}{l}\text { Productivity } \\
\text { and service } \\
\text { quality }\end{array}$} & Chi-Square & $56.676^{*}$ & $39.476^{*}$ & $37.471 *$ & $62.326^{*}$ & $35.781 *$ \\
\hline & Sig. & .000 & .000 & .000 & .000 & .000 \\
\hline
\end{tabular}

Independent Variables

\begin{tabular}{|ll|}
\hline \multicolumn{2}{|l|}{ Demographic Characteristic } \\
1. & Gender \\
2. & Age \\
3. & Marital Status \\
4. & Education \\
5. & Occupation \\
6. & Income \\
\hline & \\
\hline & \\
\hline & \\
\hline 1. & Service Marketing Mix \\
2. & Product / Service \\
3. & Place \\
4. & Promotion \\
5. & People \\
6. & Process \\
7. & Physical Evidence \\
\hline
\end{tabular}

Dependent Variables

Debit Card Using Behavior

1. The period of time holding debit card

2. The reason for holding

3. The average times per month for using

4. The period of month for the most using

5. The festival that using the debit card

6. The product/service categories to buy via debit card

7. The influence for using
1. Tangibles

2. Reliability

3. Responsiveness

4. Assurance

5. Empathy

Figure 1. The conceptual framework 